\title{
Bacterial translocation in rats nonfunctioning diverted distal colon ${ }^{1}$
}

\author{
Translocação bacteriana no coto colônico distal desfuncionalizado de ratos
}

\author{
Francisco Edilson Leite Pinto Júnior ${ }^{2}$, Carlos Teixeira Brandt ${ }^{3}$, Aldo da Cunha Medeiros ${ }^{4}$, Ariano José Freitas de \\ Oliveira $^{5}$, Selma Maria Jerônimo ${ }^{6}$, Helena Marques Fonseca de Brito ${ }^{7}$
}

1. Research performed at Federal University of Pernambuco (UFPE), Brazil.

2. PhD, Associate Professor of Surgery, Federal University of Rio Grande do Norte (UFRN), Brazil.

3. Head Professor, Pediatric Surgery, UFPE, Brazil.

4. Head Professor, Surgery, UFRN, Brazil.

5. Fellow PhD degree, UFRN, Brazil.

6. PhD, Associate Professor of Biochemistry, UFRN, Brazil.

7. Microbiology Specialist, Rio Grande do Norte, Brazil.

\begin{abstract}
Purpose: To investigate whether the alterations of the diverted colon segment mucosa, evidenced in fecal colitis, would be able to alter Bacterial Translocation (BT). Methods: Sixty-two Wistar male rats ranging from 220 to 320 grams of weight, were divided in two groups: A (Colostomy) and B (Control), with 31 animals each one. In group A, all animals underwent end colostomy, one stoma, in ascending colon; and in the $70^{\text {th }}$ POD was injected in five rats, by rectal route diverted segment - $2 \mathrm{ml}$ of a $0.9 \%$ saline solution in animals (A1 subgroup); in eight it was inoculated, by rectal route, $2 \mathrm{ml}$ of a solution containing Escherichia coli ATCC 25922 (American Type Culture Collection), in a concentration of $10^{8}$ Colony Forming Unit for milliliters (CFU/ml) - A2 Subgroup; in ten animals the same solution of E. coli was inoculated, in a concentration of $10^{11} \mathrm{CFU} / \mathrm{ml}$ (A3 Subgroup); and in eight it was collected part of the mucus found in the diverted distal colonic segment for neutral sugars and total proteins dosage (A4 subgroup). The animals from the group B underwent the same procedures of group A, but with differences in the colostomy confection. In rats from subgroups A1, A2, A3, B1, B2, and B3 2ml of blood were aspirated from the heart, and fragments from mesenteric lymphatic nodule, liver, spleen, lung and kidney taken for microbiological analysis, after their death. This analysis consisted of evidencing the presence of $E$. coli ATCC 25922 CFU. Mann-Whitney and ANOVA Tests were applied as analytic techniques for association of variables. Results: The occurrence of BT was evidenced only in those animals in which inoculated concentration of $E$. coli ATCC 25922, reached levels of $10^{11} \mathrm{CFU} / \mathrm{ml}$, i.e. in Subgroups A3 and B3, although, being significantly greater (80\%) in those animals without colostomy (subgroup B3) when compared to the ones with colostomy (20\%) from the subgroup A3 ( $\mathrm{P}<0.05)$. Lung, liver and mesenteric lymphatic nodules were the tissues with larger percentile of bacterial recovery, so much in subgroup $A 3$, as in $B 3$. Blood culture was considered positive in $60 \%$ of the animals from subgroup B3 and in 10\% of those from subgroup A3 ( $\mathrm{p}<0.05)$. There was greater concentration of neutral sugars, in subgroup A4 - mean 27.3mg/ml -, than in subgroup B4 - mean 8.4mg/ml - $(\mathrm{P}<0.05)$. Conclusion: The modifications in the architecture of intestinal mucosa in colitis following fecal diversion can cause alterations in the intestinal barrier, but it does not necessarily lead to an increased frequency of BT.
\end{abstract}

Key words: Bacterial Translocation. Colitis. Rats, Wistar.

\section{RESUMO}

Objetivo: Investigar se as alterações do cólon desfuncionalizado, evidenciadas na colite de derivação fecal, seriam capazes de permitir Translocação Bacteriana (TB), ou se a mucosa intestinal atrofiada permitiria a passagem de bactérias para órgãos à distância. Métodos: Foram utilizados 62 ratos Wistar, machos, pesando entre 220 e 320 gramas, divididos em dois grupos: A (Colostomia) e B (Controle), contendo cada um 31 animais. No grupo A, os animais foram submetidos à colostomia, terminal boca única, em cólon ascendente. A partir do $70^{\circ}$ dia de observação os seguintes procedimentos foram adotados: em cinco ratos foi injetado por via retal - no segmento desfuncionalizado - 2ml de uma solução salina 0,9\% nos animais (subgrupo A1); em oito inoculou-se, por via retal, uma solução de $2 \mathrm{ml}$ contendo Escherichia coli ATCC 25922 (American Type Culture Collection), na concentração de $10^{8}$ Unidades Formadoras de Colônias por mililitros (UFC/ml) - Subgrupo A2; em dez animais inoculava-se a mesma solução de E. coli, na concentração de $10^{11} \mathrm{UFC} / \mathrm{ml}$ (Subgrupo A3); e em oito colhia-se o muco do segmento colônico distal desfuncionalizado, para dosagens de açúcares neutros e proteínas totais (subgrupo A4). Os animais do grupo B foram submetidos aos mesmos procedimentos do grupo A, e não foram submetidos à colostomia. Nos animais dos subgrupos A1, A2, A3, B1, B2, e B3, após serem mortos, 
realizou-se punção cardíaca para coleta de 2ml de sangue e retiraram-se fragmentos de tecidos de linfonodo do mesocólon, fígado, baço, pulmão e rim, para análise microbiológica. Essa análise consistia em evidenciar a presença de UFC de Escherichia coli ATCC 25922. Os testes de Mann-Whitney e Anova foram aplicados como técnicas investigativas para associação das variáveis. Resultados: A ocorrência de TB, só foi evidenciada nos animais em que a concentração inoculada de Escherichia coli ATCC 25922, atingia níveis de $10^{11} \mathrm{UFC} / \mathrm{ml}$, ou seja, nos Subgrupos A3 e B3, no entanto, sendo significantemente superior (80\%) nos animais sem colostomia (subgrupo B3) quando comparados com os ratos com colostomia (20\%) do subgrupo A3 $(\mathrm{P}<0,05)$. Pulmão, fígado e linfonodo foram os tecidos com maior percentual de recuperação bacteriana, tanto no subgrupo A3, quanto no B3. A hemocultura foi positiva em $60 \%$ dos animais do subgrupo B3 e em 10\% do subgrupo A3 (p<0,05). Houve maior concentração de açúcares neutros, no subgrupo A4 média 27,3mg/ml -, do que no subgrupo B4 - média 8,4mg/ml - $(\mathrm{P}<0,05)$. Conclusão: As modificações na arquitetura da mucosa intestinal na colite de derivação fecal podem promover alterações na barreira intestinal, mas não necessariamente conduzem a maior freqüência de TB.

Descritores: Translocação Bacteriana. Colite. Ratos Wistar.

\section{Introduction}

Bacterial translocation (BT) is the passage of viable intestinal bacteria and endotoxins through the intestine wall for the mesenteric lymphatic nodules, to other organs and systemic circulation ${ }^{1-4}$. This phenomenon is associated with bacteremia and septicemia, renal failure and pulmonary dysfunction, which can lead to multiple organ failure, and occasionally death. In the necropsy of some cases the main focus of infection seems to have origin in the bowell ${ }^{2,3}$. It is possible to prove BT in approximately $16 \%$ of the patients who had undergone laparotomy as septicemia is found in $41 \%$ of them. Escherichia coli is the most prevalent bacteria in those cases $^{1,4}$. Alterations on the intestine mucosa barrier, as well as changes in the micro biota, changes associated with: shock; total parenteral nutrition (TPN); prolonged antibiotic therapy, bowel obstruction; severe burns; use of immune suppressors and cytoxic drugs; and intestinal manipulation during surgical procedure, are considered predisposing factors for development of $\mathrm{BT}^{5}$. In addition of digesting and absorbing nutrients, the intestinal mucosa works as an important barrier mechanism, which not allow the passage of bacteria and endotoxins, as well as other elements from the bowel tube for places outside the intestine ${ }^{5}$. Patients who undergo TPN present many more septic complications as compared with patients who are receiving enteric nutrition. The lack of nutrients in the bowel tube can cause intestine cell malfunction, as well as mucosa atrophy, which can facilitate $\mathrm{BT}^{5,6}$. Colitis following fecal diversion is a clinical condition found in almost $100 \%$ of patients who undergo colostomy and nonfunctioning colon; this surgical procedure leads to atrophy of colon mucosa, which can produce $\mathrm{BT}^{7,8}$. In some cases when colostomy results in diverted dysfunctional colon colitis following fecal diversion can occur. There are few studies on this condition and none on the possible association with BT. Thus, the purpose of this study was to investigate whether the histology changes in the dysfunctional colon and the colitis following fecal diversion would facilitate the development of BT.

\section{Methods}

Sixty-two Wistar male rats were enrolled in the study. Weights ranged from 220 and 320 grams. The rats were kept in the animal house of the Experimental Operating Room "Prof. Travassos Sarinho" -. Department of Surgery - Health Sciences Center Federal University of the Rio Grande do Norte State (UFRN), Brazil. During the study period the animals were kept in adequate environment and in individual cages with day night cycle of 12 hours. They were fed with standard diet formulation and water ad libido. Strict ethical principles aiming at protecting animals were observed and the experimental protocol was approved by the Ethical Committee - Health Sciences CenterUFRN, Brazil. There was scientific cooperation from the Laboratory of Biochemistry - Health Sciences Center (UFRN), and also from the Laboratory of Microbiology - Center of Clinical Pathology, Natal Capital City of Rio Grande do Norte State, Brazil. Study Protocol: The animals were divided in two groups: A and B, each including 31 rats. The animals from A group -, called colostomy or study group, as well as the animals in group $\mathrm{B}$ (control) were stratified in four subgroups:

Subgroup A1 (colostomy + inoculation of $0.9 \%$ saline) - There were five rats in A1 subgroup. They underwent diverted colostomy as described in surgical technique. In the $70^{\text {th }}$ postoperative day (POD), $2 \mathrm{ml}$ of 0.9 saline were infused in the colon via rectum. After 24 hours the animals were killed for taking blood and tissue samples, which were sent for microbiology study.

Subgroup A2 (colostomy + Escherichia coli inoculation at $10^{8}$ concentration) - There were eight rats in A2 subgroup. They underwent diverted colostomy as described in surgical technique. In the $70^{\text {th }}$ POD, $2 \mathrm{ml}$ suspension of Escherichia coli ATCC 25922 (American Type Culture Collection), in the concentration of $10^{8} \mathrm{UFC} /$ $\mathrm{ml}$ (Unit-forming colony per $\mathrm{ml}$ ) were infused in the colon via rectum. After 24 hours they were killed for taking blood and tissue samples, which were sent for microbiology study. 
Subgroup A3 (colostomy + inoculation of Escherichia coli suspension with the concentration of $\mathbf{1 0}^{\mathbf{1 1}}$ ) - There were eight rats in A3 subgroup; and they underwent the same protocol as in subgroup A2, however the concentration of Escherichia coli suspension was $10^{11} \mathrm{UFC} / \mathrm{ml}$.

Subgroup A4 (colostomy + mucous analyses) There were eight rats in A4 subgroup. They underwent the same surgical procedure. In the $70^{\text {th }}$ POD mucous was collected from the distal dysfunctional colon for measurements of neutral sugars and total protein.

Subgroups B1 to B4 - The rats of these subgroups B (control) did not undergo colostomy; however all the other procedures performed in the animal from subgroups A were followed.

\section{Preparing the Escherichia coli suspension}

Escherichia coli ATCC 25922 (American Type Culture Collection) was cultivated in sugar cane juice supplemented with yeast extract and peptone until the growing exponential phase in 16 hours, at the Laboratory of Microbiology - Center of Clinical Pathology, Natal Capital City of Rio Grande do Norte State, Brazil. The bacteria suspensions were washed three

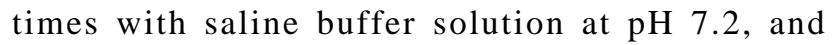
centrifuged at $1,700 \mathrm{rpm}$ for 10 minutes. The bacteria concentrates were made in suspension again using buffer phosphate. The final concentrations from $10^{8}$ to $10^{11}$ $\mathrm{UFC} / \mathrm{ml}$ were adjusted using spectrometry ${ }^{9}$.

\section{Surgical technique}

The animals of group A (experimental) were kept fasted (just drinking pure water) for 12 hours before the surgical procedure. After anesthesia with ether inhalation the animal underwent colon clean-up per rectum with, aiming to withdraw all fecal material from the colon. The rats were weighted and fixed at the operating table. Abdominal shaving was performed, followed by antisepsis with topic solution of povidine iodine (PVPI). An approximately 4cm midline laparotomy was performed for identification of the ascending colon. About $2 \mathrm{~cm}$ distal to the ileo cecal valve the colon was sectioned with previous ligature with 2-0 silk, closing the two ends of the colon. The distal segment of the colon was kept inside the abdomen and the proximal was brought up through the abdominal wall, left to the incision; early maturation of the colostomy was performed. The abdominal cavity was kept under irrigation with saline throughout the operative period, for avoiding that the bowel turn out dry. The wound was closed with 4-0 nylon stitches. The rats were observed during the postoperative period in individual cages. Diet was normal. The animals from subgroups A1, A2 and $A 3$, in the $70^{\text {th }} \mathrm{POD}$, underwent ether anesthesia for receiving rectal infusion of: $2 \mathrm{ml}$ of saline (subgroup A1); $2 \mathrm{ml}$ of Escherichia coli suspension at concentration of $10^{8} \mathrm{UFC} / \mathrm{ml}$ (subgroup A2); and $10^{11} \mathrm{UFC} / \mathrm{ml}$ (subgroup A3). After 24 hours the rats were killed with an overdose of ether for obtaining blood and tissue samples for microbiology. The animals from subgroup A4 were also killed in the 70th POD for obtaining mucous from the distal nonfunctioning colon for measurements of neutral sugars and total protein.

\section{Obtaining samples}

All animals from subgroups A1, A2, A3, B1, B2 and $\mathbf{B} 3$, after being killed, had their abdomen and thorax surgically sterile opened for collecting tissue samples, which were sent for microbiology. Heart punch was performed for collecting $2 \mathrm{ml}$ of blood, which was also sent for microbiology Tissue fragments were taken in the following order: mesenteric lymphatic nodule from the nonfunctioning colon segment (subgroups A1, A2, and A3), or descending colon (subgroups B1, B2 and B3); and fragments from left liver lobe, spleen, inferior pole of kidney and inferior lobe of the left lung. All tissue fragments were taken using individually sterile specific scissors and forceps. The samples were conditioned in sterile tubes with $1 \mathrm{ml}$ of sterile saline. The tissue fragments were carefully electronically weighted.

\section{Obtaining mucus}

The animals from subgroups A4 and B4, after being killed, had the nonfunctioning colon removed in subgroup A4, and also the descending colon in subgroup B4. After opening these colon segments the inside mucus were collected with sterile instruments and conditioned in Eppendorf tubes with phosphate buffer solution, $\mathrm{pH}$ 7.4 .

\section{Microbiology}

All tissue samples were sterile grained and diluted in a $2 \mathrm{ml}$ saline tube, under sterilized closed system in a laminar cabinet. Sample solutions were inoculated in Petri dishes containing agar MacConkey medium, selective for gram negative bacteria growth. Escherichia coli colonies were identified by their red and pink color and numbered. Positive samples were identified when presented at least 1 UFC. If there was suspected contamination in any animal, it was automatically changed for other one. Phenotypic identification of Escherichia coli ATCC 25922 (American Type Culture Collection) was automatically performed by Vitelí bioMérieux system, which can identify more than 200 bacteria species, using 30 different biochemistry tests. 
It can also identify control strain. The blood samples were inoculated in HEMOCULT I system, which were inspected daily for observing bacteria growth.

Neutral sugar and total protein analysis of the mucous

Neutral sugar concentrations from the intestine mucous were assessed by the Yemm e Wlllis ${ }^{10}$ method $500 \mu \mathrm{l}$ of water was added to $10 \mu \mathrm{l}$ sample and $2.5 \mathrm{ml}$ of antrona (reagent). The tube was stirred and sealed with aluminum paper. The final solution was warmed at 100 ${ }^{0} \mathrm{C}$ for a period of 15 minutes. After 10 minutes with a solution cooled the concentration readings were performed using a photo colorimetric dosage at $620 \mathrm{~nm}$. Total protein concentration from the intestine mucous was measured by the bicincronic acid (BCA), using the Smith method ${ }^{11}$.

\section{Statistical analysis}

Mann-Whitney and ANOVA variance were used for statistical analysis. The software Statistics version 5.0 was used. $\mathrm{p}<0.05$ was used for rejecting the null hypothesis.

\section{Results}

Six animals were substituted, with no loss for the research; four of them were excluded due to a suspicion of external contamination, being verified the presence of Agro bacterium tumefaciens and two were also excluded because they died during the experiment due to intestinal obstruction, secondary to colostomy stenosis. In Table 1 one can observe the descriptive statistics of the frequency for bacterial translocation, which was registered only in the animals submitted to inoculation of E. coli in a concentration of $10^{11}$ (A3 and B3 subgroups). It is observed that $80 \%$ of the animals that were not submitted to the colostomy, presented bacterial translocation, while, the rats submitted to the procedure, the registration decreased to $20 \%$ of the analyzed animals. It can be observed, in Table 2, that the animals that underwent colostomy presented a greater frequency of bacterial recovery (PBR) in the organs and tissues analyzed, showing differences statistically significant between the groups A3 and B3 ( $p<0.05$; ANOVA). PRB of the kidney was observed in the totality, only in the rats submitted to E. coli $10^{11}$ without colostomy (subgroup B3). In the animals that underwent colostomy there was no indication of bacterial recovery in that organ. Escherichia coli ATTCC were positively found in the blood of $10 \%$ from the rats in subgroup A3 and in $60 \%$ from the blood of rats in subgroup B3. It was observed a greater concentration of neutral sugars
(Figure 1) and total proteins (Figure 2) in the mucous of the animals that underwent colostomy, A4 and B4, (P $<0.05)$.

TABLE 1 - Frequency of bacterial translocation (BT) by subgroups

\begin{tabular}{lll}
\hline Subgroup & BT/Total & $\%$ \\
\hline A1 & $0 / 5$ & 0,0 \\
A2 & $0 / 8$ & 0,0 \\
A3 & $2 / 10$ & $\mathbf{2 0 , 0}$ \\
B1 & $0 / 5$ & 0,0 \\
B2 & $0 / 8$ & 0,0 \\
B3 & $8 / 10$ & $\mathbf{8 0 , 0}$ \\
\hline
\end{tabular}

TABLE 2 - Frequency of bacterial recovery from the organs and tissues analyzed in the animals of A3 and B3 subgroups

\begin{tabular}{lll}
\hline & \multicolumn{2}{c}{ Subgroups } \\
\cline { 2 - 3 } Organs & A3 & B3 \\
Lung & $\%$ & $\%$ \\
Spleen & 20 & 80 \\
Liver & 10 & 40 \\
Kidney & 20 & 80 \\
Linphnode & 0 & 40 \\
\hline
\end{tabular}

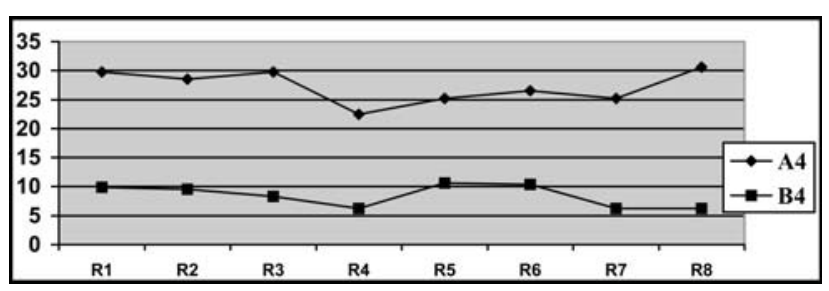

FIGURE 1 - Concentration of neutral sugars for A4 and B4 subgroups (mg/ml)

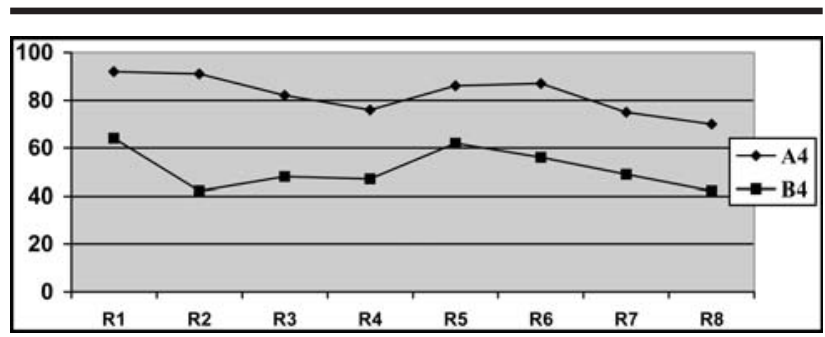

FIGURE 2 - Concentration of Total Proteins for A4 and B4 subgroups (mg/ml) 


\section{Discussion}

Although there has been progress in surgery, the control of infection remains a great challenge. From 593,344 surgical operations performed in the United States from 1986 to 1996, 15,525 (3\%) were followed by infection. From 551 infected patients who died 77\% of the deaths were due to severe infection that had led to multiple organ failure (MOF) ${ }^{12}$. Since MOF was recognized it has been one of the most frequent causes of mortality in surgical patients, especially in those cared for in Intensive Care Unit (ICU) ${ }^{13}$. Several insults including: trauma; liver resections; pancreatitis; and shock, can cause MOF, which once present may not respond to treatment, especially when the basic cause can no be overcome ${ }^{13}$. There has been, in the last years, an increase in the number of publications with focus on $\mathrm{BT}^{9,13-19}$. The experimental models represent a good tool for studying the genesis of diseases and research of new therapeutic techniques ${ }^{8}$. Among the studies, those related to total parenteral nutrition (TPN) as cause of $\mathrm{BT}^{20,21}$. It is known that TPN promotes atrophy and increases permeability of the bowel mucosa, which can promote impairment of the intestinal mucosal barrier, and consequently increase in the rate of infection complication. The lack of nutrients in the bowel tube, apart from promoting decrease of the enterocyte immune protection it produces changes in the normal intestinal micro biota, which together can cause BT. They also produce a decrease in the s-IgA production ${ }^{9,13}$. Rats were chosen for the present investigation because it's low cost and the easy management of these animals. They also present similarity of the bowel mucosa histology with that of human, as well as for being frequently used as animal model for studying $\mathrm{BT}^{2,6,9,13,15}$. Taking into consideration the atrophic effect of nonfunctioning diverted colostomy, it points out to the importance of the bowel tube content in the genesis of derivative colitis $(\mathrm{DC})^{7,8}$; since it is installed there are conditions for BT, similar to those of patients in TPN. These are the reasons because the option for this research method was taken. It is known that experimental DC is associated with a decrease of the colon mucosal thickness, after ten days, in rats that underwent colostomy, and it decreases further in the $70^{\text {th }}$ post-operative day ${ }^{8}$. Furthermore, it was observed that in DC that in the nonfunctioning colon segment, the micro biota suffered quantitative and qualitative changes. According with Neut et $\mathrm{al}^{22}$, the phenomenon is similar in humans, and the main changes is reduction of anaerobic bacteria content; interestingly the aerobic bacteria content did not undergo alterations. Since there is a decrease in anaerobic bacteria content, immune mechanism resistance is altered, and the enterocyte ability against bacteria is impaired, affecting the intestinal barrier, and facilitating $\mathrm{BT}^{6}$. Lack of bile salts in the gastrointestinal tube can also produce similar effect $^{9,18,23}$. One can not forget that, especially in rats, the s-IgA is almost in the bile. When derivative colitis occurs in nonfunctioning colon, there is no bile salts, and consequently decrease in s-IgA concentration affecting the immune system of this colon segment. The bowel motility involving the migratory motor complex (MMC) is implicated in the regulatory mechanism avoiding bacteria growth. Scoot et $\mathrm{al}^{24}$ observed in rats that the high dose of morphine produces impairment of intestinal MMC promoting BT. It is also known after colostomy that there is decrease in normal peristaltic movements in the distal non functioning colon segment. These waves works as a true intestine washout, and when they are altered there is a change in the peristaltic threshold facilitating fecal stasis, and consequently increasing the probability of bacteria penetrate in the mucous barrier producing epithelial adherence ${ }^{13}$. For all these alterations found in nonfunctioning colon segment in DC, they facilitate BT by altering the colon environment. The majority of papers about BT are based on small bowel as origin of this phenomenon. This is one of the reasons because colon in rat was chosen as subject of the present investigation. Up to the time of this study there was only one experimental investigation on this subject -, Koh et $\mathrm{al}^{2}$ experimentally studied BT process in the large bowel. They found, using different concentrations $\left(2 \times 10^{5} ; 2 \times 10^{8} ; 2 \times 10^{11}\right)$ of E.coli R6 inoculated in rats, both in the small and large bowel, that BT could be produced. However, they stressed that BT occurred only when the concentration was $2 \times 10^{11}$. Similar to the present study there was BT only in subgroups A3 and B3; in these subgroups the Escherichia coli concentrations were also $2 \times 10^{11}$. The results are in accordance with the study of Cruz et al, who demonstrate in vitro that the BT process is concentration dependent, which means that the greater bacteria concentration is associated with grater possibility of $\mathrm{BT}^{25}$. In experimental studies ${ }^{2,6,9,13,15}, E$. coli is the bacteria more frequently found in the BT process -, up to $91 \%$ found in organs and tissues outside the bowel. The anaerobic bacteria rarely produces BT. This fact is the reason because $E$. colli was the choice for this investigation. There is a predisposition of bacteria adherence to the distal intestine tube, which is related to the abundance of receptors ${ }^{13}$ in the edge of colon mucosa through the specific lecithin expression; normally present in the epithelial cells of the host ${ }^{20}$. The identification of $E$. coli ATCC 25922, in the present study, was done using the Vitelí bioMérieux method, which is considered of low cost, easy and trusted with sensibility and specificity greater than 98\%; in all dishes where results were similar to the inoculated bacteria the phenotypic features were tested and proved to be ATCC 25922 type. Furthermore, the absence of bacteria in tissue samples from rats that receives saline per rectum infusion (subgroups A1 and B1) gives further support to this hypothesis. 
It is important to stress that the assessment of BT using microbiology investigations can underestimated the phenomenon. Kane et al observed that the frequency of positive blood culture in patients who had undergone surgery increased from $14 \%$, as routine blood culture was the tool for investigation, to $64 \%$ when bacteria DNA identification using Polymerase Chain Reaction (PCR) was used ${ }^{26}$. However, this is an expensive and complex method, not available in all research institutions. Taking into account the microbiology method had interfered in the results of the present investigation, underestimating the frequency of BT, it does not undermine the analytical component of the study, since the rats from groups $\mathrm{A}$ and $\mathrm{B}$ underwent the same protocol investigation; thus, if it was the case the error would be in both groups. The significant difference between subgroups A3 and B3 -, as regard to $P R B$ gives support to the main question $f$ the investigation: whether the atrophy of colon mucosa evident in DC would facilitate the development of BT. From the results of this investigation one can not conclude that there was association of con mucosa atrophy and BT. The first step for BT from the bowel is bacteria adhesion to the epithelium surface. This cell property is important in determining the virulence of the majority of pathogenic bacteria ${ }^{9}$. However for adhesion is necessary that the bacteria penetrate the intestine mucus inner part. This important defense was emphasized by Florey $^{27}$, in 1933. He mentioned that the mucus layer would act as a barrier mechanism, slowing down or avoiding that bacteria from the bowel tube could grow in the epithelial surface. There are several primary components that are part of this intestine mucus layer: mucin; neutral sugars; and total proteins, among others, which in decreasing would provide the environment for developing BT. These components increases the mucus viscosity and elasticity, facilitating the enteric bacteria union with immunoglobulin -, especially with s-IgA, thus, blocking the bacteria adhesion with the receptors of the epithelial cells, preventing mucosa colonization; and by consequence avoiding $\mathrm{BT}^{17}$. This fact was proved by Katayama et $\mathrm{al}^{28}$, in 1997 . They proved experimentally that there were endotoxin high levels in the blood stream from rats that presented significant decrease in mucin of the bowel mucus. Neutral sugar and total protein concentrations were evaluated in the present study, either in animals with (subgroup A4) and without (subgroup B4) colostomy. The results point out for greater mucus concentration for both neutral sugars and total proteins in the rats with nonfunctioning colon (subgroup A4). It means the mucus turned out thicker and with more viscosity in the nonfunctioning colon, when compared with that from normal colon. This fact was observed when mucus was collected. There was a clear difference in mucus viscosity from the subgroups A4 and B4. It is likely that this difference was one of the factors responsible for the low $\mathrm{BT}$ in rats from group $\mathbf{A}$ when compared with animals from group B.

\section{Conclusion}

Alterations in the colon mucosa architecture from rats with colitis following fecal diversion may promote changes in bowel barrier. However they are not necessarily associated with greater bacterial translocation.

\section{References}

1. MacFie J. Bacterial translocation in surgical patients. Ann R Coll Surg Engl. 1997; 79 (3): 183 - 9.

2. Koh IHJ, Guatelli EFS, Montero, R, Keller MHG, Silva S, Goldenberg S, et al. Where is the site of bacterial translocation- smal or large bowel? Transplant Proc. 1996; 28 (5): 2661.

3. Deitch EA. Multiple organ failure. Ann Surg. 1992; 216: 127-34.

4. Sedman PC, MacFie J, Sagar P. The prevalence of gut translocation in humans. Gastroenterology. 1994; 107: 643- 9.

5. Fink MP. Effect of critical illness on microbial translocation and gastrointestinal mucosa permeability. Seps Respir Infect. 1994; 9 (3): 256-60.

6. Tamayo FG, Valdes LIT, Lopez NM. Bacterial translocation and wasting in stressed mice. Arch Med Res. 1996; 27 (2): 115-21.

7. Pinto Jr. FEL, Medeiros AC, Oliveira AJF, Medeiros KF, Ramos AMO. Colite de derivação fecal. Rev Col Bras Cir. 1999; 26 (3): 185-9.

8. Pinto Jr. FEL, Oliveira AJF, Medeiros KF, Ramos AMO, Ramos CCO, Medeiros AC. Repercussões histopatológicas da colostomia no coto colônico distal desfuncionalizado: estudo experimental em ratos. Rev Col Bras Cir. 1999; 26 (6): 327-33.

9. Rocha Sl. Recuperação em órgãos e tecidos de Escherichia coli ATCC 25922, inoculada no íleo terminal de ratos com obstrução intestinal [Tese Doutorado]. Paraná; 1999.

10.Yemm EW, Willis AJ. The estimation of carbohydrates in plant extracts by anthrone. Biochem J. 1954; 57: 508-15.

11. Smith PK. Measurement using bicinchoninic acid. Anal Biochem. 1985; 150: 76-85.

12. Medeiros AC, Aires Neto T, Dantas Filho AM, Pinto Jr FEL, Uchoa RAC, Carvalho MR. Infecção hospitalar em pacientes cirúrgicos de hospital universitário. Acta Cir Bras. 2003; 18(1): 15-8.

13. Castro LS. Translocação bacteriana e peroxidação lipídica na obstrução intestinal em ratos [Tese Doutorado]. Rio de Janeiro; 1999.

14. Nieuwenhuijzen GAP, Goris RJA. The gut: the motor of multiple organ dysfunction syndrome? Curr Clin 
Nutr Metab Care 1999; 2 (5): 399-404

15. Alencar SSS, Medeiros AC, Brandt CT, Aguiar JLA, Rocha KBF, Silva MP. Translocação de bactérias marcadas com $\mathrm{Tc}^{99}$ na icterícia obstrutiva em ratos. Acta Cir Bras. 2001; 17 (Suppl 1): 35-8.

16. Alexander JW, Boyce ST, Babcock GF, Gianotti L, Peck MD, Dunn DL et al. The process of microbial translocation. Ann Surg. 1990; 212 (4): 496-512.

17. Deitch EA, Rutan R, Waymack JP. Trauma, Shock and gut translocation. Am Coll of Gastroenterology. 1998; 93(2): 277-8.

18. O’Boyle CJ, MacFie J, Dave K, Sagar OS, Poon P, Mitchell CJ. Alterations in intestinal barrier function do not predispose to translocation of enteric bacteria in gastroenterologic pacients. Nutrition. 1998; 14(4): 358-62.

19. Deitch EA. Bacterial translocation or lymphatic drainage of toxic products from the gut: what is important in human beings? Surgery 2002; 131(3): 241-4.

20. MacFie J. Enteral versus parenteral nutrition: the significance of bacterial translocation and gut-barrier function. Nutrition. 2000; 16(7): 606-11.

21. Kudsk Ka, Croce MA, Fabian TC, Minard G, Tolley EA, Poret A et al. Enteral versus parenteral feeding.
Effects on septic morbidity after blunt and penetrating abdominal trauma. Ann Surg. 1983; 23(4): 503-13.

22. Neut C, Colombel JF, Guillemot F, Cortot A, Gower $\mathrm{P}$, Quandalle P, et al. Impaired bacterial flora in human excluded colon. Gut. 1989; 30 (8): 1094-8.

23. Bailey ME. Endotoxin, bile salts and renal function in obstructive jaundice. Br J Surg. 1976; 63 (2): 774-8.

24. Scott LD, Cahall DL. Influence of the interdigestive myoeletric complex on enteric flora in the rat. Gastroenterology. 1982; 82: 737-45.

25. Cruz N, Lu Q, Alvarez X, Deitch EA. Bacterial translocation is bacterial species dependent: results using the human Caco-2 intestinal cell line. J Trauma. 1994; 36 (5): 612-6.

26. Kane TD, Alexander JW, Johanningman JA. The detection of microbial DNA in the blood. Ann Sur 1998, 227 (1): 1-9.

27. Florey HW. Observations on the functions of mucus and the early stages of bacterial invasion of the intestinal mucosa. J Pathol Bacteriol 1933; 37: 283-9.

28. Katayama M, Xu D, Specian R, Deitch EA. Role of bacterial adherence and the mucus barier on bacterial translocation: effects of protein malnutrition and endotoxin in rats. Ann Surg. 1977; 225 (3): 317-26.

\section{Correspondence:}

Francisco Edílson Leite Pinto Junior

Rua: Pinto Martins, 1044/302

59014-060 Natal - RN Brazil

edilsonpinto@uol.com.br
Conflict of interest: none Financial source: none

Received: January 15, 2007

Review: February 12, 2007

Accepted: March 16, 2007

\section{How to cite this article}

Pinto Jr FEL, Brandt CT, Medeiros AC, Oliveira AJF, Jerônimo SM, Brito HMF. Bacterial translocation in rats nonfunctioning diverted distal colon. Acta Cir Bras. [serial on the Internet] 2007 May-June;22(3). Available from URL: http://www.scielo.br/acb 